УДК 82I.I6I.3 + 82I.I6I.I

ББК 83.3(4Беи) +

$83.3(2 \mathrm{Poc}=\mathrm{Pyc}) 6$
АЛЛЮЗИЯ НА ЕВАНГЕЛЬСКИЕ СЮЖЕТЫ
В РОМАНАХ «ХРИСТОС ПРИЗЕМЛИЛСЯ
В ГОРОДНЕ» В. КОРОТКЕВИЧА И
«МАСТЕР И МАРГАРИТА» М. БУЛГАКОВА

(C) 2020 г. Н.В. Яковенко

Институт литературоведения

имени Янки Купалы Центра исследований бело-

русской культуры, языка и литературы Нацио-

нальной академии наук Беларуси,

Минск, Республика Беларусь

Дата поступления статьи: о8 февраля 2019 г.

Дата публикации: 25 марта 2020 г.

DOI: I0.22455/2500-4247-2020-5-I-2I2-227

Аннотация: В статье на основе сопоставительного анализа текстов романов «Христос приземлился в Городне» классика белорусской литературы Владимира Короткевича и «Мастер и Маргарита» классика русской литературы Михаила Булгакова рассматриваются типологические сходства и отличия в художественном осмыслении евангельских сюжетов. Сравнивая сюжеты романов с текстом Евангелия от Матфея (5: 9-I4; 9: 27-3I) и Евангелия от Марка (15: 2025), автор анализирует аллюзию белорусского писателя на Нагорную проповедь Иисуса Христа, на излечение слепых, аллюзию В. Короткевича и М. Булгакова на евангельский концепт «по вере вашей да будет вам» и на восхождение Христа на Голгофу. Вместе с тем автор статьи подчеркивает антиатеистический, а не антирелигиозный характер произведений, построенных по принципам эстетической игры. Проведенное исследование позволило сделать следующие выводы: романы В. Короткевича и М. Булгакова не претендуют на изложение или толкование Евангелия, а являются только развернутыми аллюзиями на его сюжеты. Евангельская тематика в произведениях подчинена освещению вопросов соотношения добра и зла, духовного и материального, истины и лжи, власти и справедливости.

Ключевые слова: Евангелие, аллюзия, Владимир Короткевич, Михаил Булгаков, роман, концепт, травестийность, фарсовость.

Информация об авторе: Наталья Васильевна Яковенко - кандидат филологических наук, научный сотрудник, Институт литературоведения имени Янки Купалы Центра исследований белорусской культуры языка и литературы Национальной академии наук Беларуси, ул. Сурганова, д. I, корп. 2, 220072 г. Минск, Республика Беларусь.

E-mail: natayakavenka@tut.by

Для цитирования: Яковенко Н.В. Аллюзия на евангельские сюжеты в романах «Христос приземлился в Городне» В. Короткевича и «Мастер и Маргарита» М. Булгакова // Studia Litterarum. 2020. Т. 5, № І. С. 212-227.

DOI: $10.22455 / 2500-4247-2020-5-\mathrm{I}-2 \mathrm{I} 2-227$ 


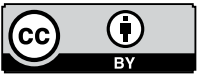

This is an open access article distributed under the Creative Commons Attribution 4.0 International (CC BY 4.0)

\section{ALLUSIONS TO THE GOSPEL STORIES IN CHRIST LANDED IN HARODNIA BY V. KOROTKEVICH AND MASTER AND MARGARITA BY M. BULGAKOV}

(C) 2020. N.V. Yakovenko Yanka Kupala Institute of Literary Studies of the Center for Belarusian Culture, Language and Literature Research of the National Academy of Sciences of Belarus, Minsk, Republic of Belarus

Received: February 08, 2019

Date of publication: March 25, 2020

Abstract: This article examines typological similarities and differences in the literary interpretation of Gospel plots based on comparative analysis of the texts of the novels Christ Landed in Harodnia by the classic of Belarusian literature Vladzimir Korotkevich and Master and Margarita by the classic of Russian literature Mikhail Bulgakov. Comparing the plots of the novels with the texts of the Gospel of Matthew (5: 9-I4; 9: 27-3I) and the Gospel of Mark (I5:20-25), the author analyzes the allusion of the Belarusian writer to the Sermon on the Mount of Christ, to the healing of the blind, the allusion of V. Korotkevich and M. Bulgakov to the evangelical concept "according to your faith be to you", and the ascent of Christ to Calvary in the novels Christ Landed in Harodnia and Master and Margarita. At the same time, the article emphasizes the antiatheistic and non-anti-religious nature of the novels built on the principles of aesthetic play. The research leads to the following conclusions: the novels by V. Korotkevich and M. Bulgakov do not pretend to expound or interpret the Gospel, instead they are extended allusions to to the Gospel's themes. The Gospel theme in the works is part of the broader framework that explores the relation between good and evil, spiritual and material, between truths and lies, between power and justice.

Keywords: Gospel, allusion, Vladzimir Korotkevich, Mikhail Bulgakov, novel, concept, travesty, farcical.

Information about the author: Natalya V. Yakovenko, PhD in Philology, Researcher, Yanka Kupala Institute of Literary Studies of the Center for Belarusian Culture, Language and Literature Research of the National Academy of Sciences of Belarus, Surganov St. I, build. 2, 220072 Minsk, Republic of Belarus.

E-mail: natayakavenka@tut.by

For citation: Yakovenko N.V. Allusions to the Gospel Stories in Christ Landed in Harodnia by V. Korotkevich and Master and Margarita by M. Bulgakov. Studia Litterarum, 2020, vol. 5, no I, pp. 2I2-227. (In Russ.) DOI: IO.22455/2500-4247-2020-5-I-2I2-227 
Сущность бытия является наиболее сложной основополагающей проблемой философии, затронутой впервые древнегреческим мыслителем Парменидом (около 540-470 гг. до н. э.) и не решенной до настоящего времени. С появлением Библии, первые тексты которой датируются IV в. н. э., философские споры о сущности бытия приобрели религиозный характер, чему в особо значимой мере послужила евангельская история рождения, деяний, учения, смерти, воскресения и вознесения Иисуса Христа. Около двух тысяч лет Его образ в неоднозначной, часто парадоксальной, противоречащей Евангелию трактовке постоянно используется в культуре, располагая не только к философским размышлениям, но и к религиозным или антирелигиозным спорам.

В мировой художественной литературе XX в. наиболее яркое персонифицированное воплощение образ Иисуса Христа получил в романах «История Христа» (I92I) итальянского писателя Джованни Папини, «Последнее искушение Христа» (I95I) греческого писателя Никоса Казандзакиса, «Мастер и Маргарита» (1967) русского писателя Михаила Булгакова, «Семь лун, семь змей» (г970) латиноамериканского писателя Деметрио Агилеры Мальта, «Христос приземлился в Городне» (1972) белорусского писателя Владимира Короткевича и в романе «Евангелие от Иисуса» (1998) португальского писателя Жозе Сарамаго, за который он был удостоен Нобелевской премии.

Белорусский исследователь творчества В. Короткевича Анатолий Воробей в предисловии к роману «Христос приземлился в Городне» [5] отмечает, что по своим художественным особенностям он стоит в одном ряду с такими произведениями мировой литературы, как «Гаргантюа и 
Пантагрюэль» Ф. Рабле, «Легенда о Тиле Уленшпигеле» Ш. де Костера, «Кола Брюньон» Р. Роллана, «Имя розы» У. Эко и «Мастер и Маргарита» М. Булгакова. При этом А. Воробей, рассматривая в основном социально-философский подтекст, исторический контекст и жанрово-стилистические особенности романа, в частности положенный в его основу принцип эстетической игры, мало внимания уделяет переосмыслению В. Короткевичем евангельского сюжета. Отдельное исследование аллюзии на евангельский образ Иисуса Христа в произведении Владимира Короткевича принадлежит белорусскому литературоведу Еве Леоновой [9], которая, однако, не проводит сопоставления ни с произведениями других писателей, ни с евангельским текстом.

Украинские ученые А. Нямцу и Е. Лабай, анализируя евангельский концепт в славянской литературе [ІІ], говорят о типологическом сходстве романов «Христос приземлился в Городне» и «Мастер и Маргарита», не прибегая к сопоставительному анализу текстов.

Российские булгаковеды Е. Иваньшина и А. Леонтьев, раскрывая особенности интертекстуальности романа «Мастер и Маргарита» [3; 8], не объясняют суть авторской эстетической игры, в том числе аллюзии на сюжеты Евангелия.

Глубоким осмыслением булгаковской аллюзии отличается книга диакона Андрея Кураева «"Мастер и Маргарита”: за Христа или против?» [7], но, поскольку исследователь не ставил перед собой задачу рассмотрения вынесенного в название вопроса в широком литературном контексте, здесь нет сопоставления с какими-либо произведениями других авторов.

Таким образом, очевидна необходимость сопоставительного анализа аллюзии на евангельские сюжеты в романах белорусского и русского классиков литературы - Владимира Короткевича и Михаила Булгакова. В рамках представленной статьи мы сосредоточимся на некоторых евангельских сюжетах, которые приобрели двусмысленное отражение в романах «Христос приземлился в Городне» и «Мастер и Маргарита», в силу чего возникла обозначенная А. Кураевым дилемма философско-эстетического характера: В. Короткевич и М. Булгаков «за Христа или против?», их произведения богоборческие или богоискательские, атеистические или антиатеистические.

«Христос приземлился в Городне» - философско-исторический роман-притча о жизни в Беларуси XVI в. Сюжет произведения 
В. Короткевича построен на основе прочитанной писателем записи в исторической «Хронике Белой Руси...» каноника М. Стриковского о появлении во время правления Сигизмунда Первого самозванца, «который с легкости какой умыслил» или, скорей, с отчаяния «имя Христа Господа себе приписал» $[4$, с. 5]. Запись вдохновила писателя на создание художественной истории путешествий и необычных свершений бывшего школяра Юрася Братчика, которого под страхом пыток и смерти иезуиты заставили назваться Христом, после чего жизненные коллизии его складывались в соответствии с евангельскими сюжетами. Так, лже-Христу пришлось спасать обездоленных от голода, угнетения и несправедливости, выгонять торговцев из храма, творить чудеса, произнести Нагорную проповедь и взойти на Голгофу.

Казалось бы, одно только название «Христос приземлился в Городне» говорит о богоборчестве, но на самом деле оно хорошо продумано автором, досконально знавшим Евангелие в советское атеистическое время (произведение писалось в 1965-1966 гг., впервые опубликовано отдельной книгой в 1972 г.). Христос, роль которого пришлось некоторое время выполнять Юрасю Братчику, на самом деле «приземлился» во время «падения огненного змея»; кроме того, именно «приземление», а не приход или пришествие Христа наилучшим образом передает травестийность и фарсовость романа, в котором постановка чрезвычайно важных вопросов общечеловеческого и национального характера осуществляется с помощью средств абсурда.

Согласно А. Нямцу и Е. Лабай, «в новозаветном сюжетно-образном материале В. Короткевича интересует в первую очередь его десакрализованная аксиологическая основа, в связи с чем многочисленные информационно значимые “сигналы-катализаторы” из канонических текстов получают объективированное рациональное истолкование (пророчества, чудеса и т. п.)» [II, с. 69]. Создавая аллюзию на евангельские сюжеты, писатель показывает не чудодейственность того, что происходит, а народную смекалку и изобретательность «земного Христа» (П. Навойчик), в результате чего сверхъестественное сводится к обычному, как в речи Юрася Братчика на Красной горе перед боем - аллюзии на Нагорную проповедь Иисуса Христа, лишенной религиозного содержания, по-земному передаются высокие нравственные истины: 
Блаженны миротворцы, если не унижен человек... Блаженны изгнанники за правду... Блаженны, если выходите с оружием за простой, бедный люд и падаете... Потому что тогда вы - соль земли и свет мира. Любите и миритесь. Но и ненавидьте тех, кто посягает на вас и вашу любовь. Мечом, занесенным над сильными, над алчными, над убийцами правды, дайте всем простым мир [6, с. 406].

Эта выдержка из речи Христа-Братчика коррелирует со следующим евангельским текстом (Мф. 5: 9-І4):

Блаженны миротворцы, ибо они будут наречены сынами Божиими.

Блаженны изгнанные за правду, ибо их есть Царство Небесное.

Блаженны вы, когда будут поносить вас и гнать и всячески неправедно злословить за Меня.

Радуйтесь и веселитесь, ибо велика ваша награда на небесах: так гнали и пророков, бывших прежде вас.

Вы - соль земли. Если же соль потеряет силу, то чем сделаешь ее соленою? <...>

Вы - свет мира. Не может укрыться город, стоящий на верху горы [I, c. IOI5].

В высказывании о миротворцах Владимир Короткевич избежал религиозности, но содержание, по сути, оставил то же самое: «если не унижен человек» во время миротворческой миссии, которую предстояло осуществить героям произведения, то миротворцы «будут наречены сынами Божиими». Евангельское высказывание «Блаженны изгнанные за правду» как бы расширяется в художественном произведении за счет фразы про тех, кто с оружием в руках сражается за обездоленных, что не противоречит евангельскому постулату насчет блаженства поносимых и гонимых за Христа, ибо заступаться за несправедливо обиженных - значит отстаивать правду и христианские ценности. И только тогда, по В. Короткевичу, можно стать «солью земли» и «светом мира».

Согласно Синодальному изданию Библии Русской православной церковью, в частности Евангелия от Матфея (9: 27-31), Иисус Христос, прикоснувшись к глазам двух слепых, которые шли за ним с просьбой избавле- 
ния от болезни и верили в возможность чудодейственного выздоровления с Божией помощью, сказал: «...по вере вашей да будет вам» [I, с. IO22] - и тем самым вернул слепым зрение.

В произведении Владимира Короткевича лже-Христос Юрась Братчик, чтобы не быть наказанным за свою вынужденную ложь, за деньги «излечивает» с помощью грязи из-под ног не двух, как в Евангелии, а трех слепых, также ложных. В. Короткевич объединяет два евангельских сюжета: один об исцелении Иисусом Христом двух слепых с помощью прикосновения, второй - об исцелении одного слепого от рождения человека с помощью скатанного из грязи шарика, которым Христос помазал глаза слепого и сказал умыть лицо в купальне Силоам, после чего тот стал видеть. При этом концептуально важная для христианства фраза не звучит, а заменяется другой:

Христос склонился, черпнул из-под ног грязь и левой рукой взял «слепого» за руку. Золотой перешел «слепому», и тот молча склонил голову: «Хватит». И тогда Христос мазнул грязью всех трех по глазам.

- Идите. Обмойтесь. Будете видеть свет небес... <..>

Они достали из-под век положенные туда половинки горошинок, проморгались и, закрыв глаза, пошли назад. <...>

Слепых подвели. Юрась перекрестил их.

- Зри! - повелел он. - Зри на Бога во славе его!

Слепой «с тяжестью» приподнял веки:

- Господи Боже, - тронулись шепотом губы. - Вижу... Вижу, Господи Боже... Созерцаю светлый лик твой!

Взглянул на сотника:

- А это что за богомерзкое рыло? [6, с. 255-256]

Фразу «Будете видеть свет небес» можно считать содержательно близкой евангельской «по вере вашей да будет вам». Однако обещание видеть свет небес не сосредоточивает внимание на одном из основных евангельских концептов - на необходимости безусловной веры в Бога. В контексте произведения, в котором действуют лже-Христос и лже-слепые, призыв к безоговорочной вере был бы не то что неуместным, а даже кощунственным с точки зрения христианства, поэтому «замена» евангельской фразы в данном случае вполне оправдана. 
Согласно Евангелию, «Иисус строго сказал им: смотрите, чтобы никто не узнал» [I, с. I022]. Лже-Христос В. Короткевича дал другой строгий наказ: «Зри на Бога во славе его!», что также противоречит евангельскому сюжету, но логично в контексте художественного произведения. Вылеченные Сыном Божиим слепые не сомневались в его величии, а сам Христос не хвастался собственными поступками и не искал славы. Братчик «работал на публику», когда совершал «чудеса» перед толпой людей, которые не безосновательно сомневались в нем как в мессии. Лже-слепые подыгрывали, поэтому продолжением призыва смотреть на Бога во славе Его стала фраза «Созерцаю светлый лик твой!», искусно «подчеркнутая» писателем противоположным по содержанию и коннотации высказыванием насчет «богомерзкого рыла» сотника.

В романе Михаила Булгакова концептуальную евангельскую фразу «по вере вашей да будет вам» в измененной формулировке произносит, как это ни парадоксально, Воланд - персонификация дьявола. Причем используется концепт безотносительно к евангельскому сюжету, как одна из «теорий», которую он упоминает, обращаясь во время бала к голове Берлиоза:

- Михаил Александрович, - негромко обратился Воланд к голове, $<. .>$ Вы всегда были горячим проповедником той теории, что по отрезании головы жизнь в человеке прекращается, он превращается в золу и уходит в небытие. Мне приятно сообщить вам, в присутствии моих гостей, хотя они и служат доказательством совсем другой теории, о том, что ваша теория и солидна и остроумна. Впрочем, ведь все теории стоят одна другой. Есть среди них и такая, согласно которой каждому будет дано по его вере. Да сбудется же это! Вы уходите в небытие, а мне радостно будет из чаши, в которую вы превращаетесь, выпить за бытие [2, с. 265].

В одновременно ироническом и философском монологе Воланда, в отличие от слов Юрася Братчика, обращается внимание на важность безоговорочной веры и могущество ее силы, что является одним из основных постулатов христианства. Однако, поскольку обращение к евангельскому концепту происходит через образ сатаны, не подчеркивается Божие величие - по-своему одаривает здесь другая сила, «что вечно хочет зла» [2, с. 7]. 
На первый взгляд использование фразы Христа в качестве постулата, сказанного сатаной в романе Михаила Булгакова, и «травестийная аллюзия на новозаветную сюжетику» (Е. Леонова) в романе Владимира Короткевича указывают на антирелигиозную направленность произведений. Однако в том и особенность романов, построенных по принципам эстетической игры, что авторский замысел скрыт очень глубоко, и понимание произведений как антирелигиозных было бы большой ошибкой.

Так, профессор богословия, диакон Андрей Кураев убедительно доказывает, что роман «Мастер и Маргарита» является не антирелигиозным, а антиатеистическим произведением. Богослов делает такой вывод: «Булгаков <...> надеялся в советской стране опубликовать антисоветский текст. Многое он замаскировал. И тем ввел в заблуждение не только советских цензоров, но и некоторых своих православных читателей. В ночном бою нередко свои же бьют своих. Булгаков как раз и вел прикрытый, ночной бой с атеизмом. Он вел бой за Христа. Но, увы, от христиан же потом и стал получать потоки критики» [7, с. І27].

Так называемая Нагорная проповедь лже-Христа достаточно отчетливо показала серьезное, вовсе не атеистическое отношение В. Короткевича к христианству, несмотря на трагикомичность и травестийность романа «Христос приземлился в Городне», на ироничность авторской манеры письма и юмористичность многих эпизодов. Подтверждением тому является также аллюзия на восхождение Христа на Голгофу - в произведении это замковая гора Воздыхальня. Аллюзию следует подробно рассмотреть в сопоставлении с описанием, содержащимся в Евангелии от Марка (Мк. І5: 20-25).

Евангелие дает краткую информацию: «Когда же насмеялись над Ним, сняли с Него багряницу, одели Его в собственные одежды Его и повели его, чтобы распять его. И заставили проходящего некоего Киринеянина Симона, отца Александрова и Руфова, идущего с поля, нести крест Его» [I, с. IO78].

Владимир Короткевич не только отступает от краткости повествования, свойственного евангельскому стилю, но и уходит от фактов, зафиксированных в Священном Писании. Над Юрасем Братчиком не насмехались до восхождения на Голгофу и не переодевали его, но пытали, когда арестовали; лже-Христа должны были не распять, а повесить на кресте; свой крест он должен был до конца нести сам. Важно также, что если евангельский 
сюжет не имеет подробного описания пути Христа к Голгофе, то в романе этому посвящено несколько глубоко психологических эпизодов.

«Тяжело идти. Пот льет со лба. Если бы воткнули в рот кляп, как предлагали, не взошел бы. Это и заставило их отказаться. <... Тяжело! Огромный крест сгибает почти пополам» [6, с. 496]. Как чувствовал себя Иисус Христос, идя к месту казни, можно только догадываться. Не исключено, что аллюзия В. Короткевича очень похожа на ту далекую от нашего времени реальность.

Обратимся далее к Евангелию: «И привели Его на место Голгофу, что значит: Лобное место. И давали Ему пить вино со смирною; но Он не принял» [I, с. I078]. С этим евангельским эпизодом перекликается следующий эпизод романа: «юрась облизнул губы. И тогда стражник хлестнул из баклаги ему в лицо. Братчик закрыл глаза. С волос, с лица плыло, смешиваясь с грязью и кровью, красное вино. Губы Христовы затряслись» [6, c. 507]. В романе, в отличие от Евангелия, над Христом-Братчиком насмехались не перед тем как отправить на Голгофу, а на месте казни, и от вина он не отказывался, но и не напился в результате издевательского поведения палача.

Необходимо подчеркнуть: Юрасю Братчику не свойственны Христовы качества - всепрощение, терпение в отношении обидчиков и покорность воле Бога-Отца. Как отмечает исследователь творчества В. Короткевича Анатолий Воробей, лже-Христос «сообразительный, находчивый, веселый, шаловливый, мошенник и притвора. Но одновременно это мыслитель и мученик, правдоискатель, народный защитник и борец. Потери, трудности и неудачи закаляют его» [5, с. 6]. В сюжете восхождения на Голгофу, в том числе в цитируемом далее отрывке из романа, заметны в характере Братчика именно эти черты правдоискателя и борца, закаленного в трудных жизненных обстоятельствах:

Когда перестали дрожать губы, он раскрыл глаза.

- Босяцкий! Лотр! Комар! - Голос звучал хрипло и шершаво и вдруг словно прорезался, затрубил, загремел: - Вы - антихристы! Вы - гниль! Я умру! Я вызываю вас на суд Божий. Месяца не пройдет, как мы встретимся. Месяца! Месяца! И тогда будете пить свою чашу вы! [6, с. 507] 
Дальнейшие события Евангелие описывает так: «Был час третий, и распяли Его» [г, с. I078]. В отличие от евангельского сюжета, лже-Христа не распяли, друзья спасли его и уничтожили карателей. Главным героем произведения является обычный человек, который не по своей воле выполнял чрезмерно тяжелую для себя, как и для любого человеческого, а не Божия сына, роль. Важно то, что невольно, рисуя картины восхождения лже-Христа на замковую гору Воздыхальню для смертной казни, писатель дал читателям возможность глубже почувствовать весь трагизм восхождения настоящего Христа на Голгофу.

В романе «Христос приземлился в Городне» аллюзия на евангельскую историю с распятием Иисуса Христа дается дважды. Первый раз - в начале произведения - комедийно, в качестве провального спектакля, в котором Юрась Братчик играл роль ангела, а роль Христа исполнял бывший дровосек Акила Киёвый:

Акила крутил руками, тужился, но все же шел вперед. Мурины скрежетали зубами и наконец взволокли его на крест.

- Ну-ка, приколачивайте, чтобы не сошел! - рыкал Пилат.

И только тут кое-кто в толпе понял: это тебе не шуточки. Кричаликричали, а тут, видишь ты, Бога распинают. <...>

Акила на кресте закинул голову, закатил глаза и испустил дух. Эфиопы отступили, чтобы с видом художников полюбоваться своею работой. И тут произошло непоправимое.

Под весом Акилы крест сложился (так его было удобнее перевозить в фургоне: складной, со ступенькой для ног, с надписью «INRI», которая только что так величественно окаймляла голову Акилы). Крест сложился, и под ним, показывая небу зад, стоял большущей перевернутой ижицей Акила Киёвый, неудавшийся Иисус [6, с. 71-72].

«Удавшимся Иисусом» стал позже Юрась Братчик, не зря его восхождение на Голгофу показано так психологически глубоко и «по-настоящему». Спектакль с Акилой Киёвым в главной роли - своего рода введение в историю пришествия, свершений и распятия Христа, описанную в романе. Поэтому доминирующей здесь является фраза о внезапном осознании зрителями того, что это не шуточки, - Бога распинают. Своим обращением 
к евангельской тематике и яркой художественной аллюзией Владимир Короткевич направил читательское внимание к Новому Завету и подчеркнул исключительную важность фигуры Иисуса Христа.

Роман Михаила Булгакова «Мастер и Маргарита» является «текстом в тексте», или «романом в романе», состоящим из романа о Мастере и романа самого Мастера. Один из центральных персонажей произведения Иешуа Га-Ноцри - аллюзия на евангельский образ Иисуса Христа.

Иешуа - не находчивый притвора и борец, как Братчик, а смиренный и тихий философ, уверенный в том, что все люди добрые. «В определенном смысле Христос был именно таким, как булгаковский Иешуа Га-Ноцри из “Мастера и Маргариты”, - объясняет Андрей Кураев. - Таким был “имидж” Христа, таким Он казался толпе» [7, с. 34].

Вот один из особенно важных эпизодов, который перекликается с Евангелием и хорошо иллюстрирует переданный М. Булгаковым «имидж» Христа:

- А скажите... напиток им давали перед повешением на столбы?

- Да. Но он, - тут гость закрыл глаза, - отказался его выпить. <...>

- Он сказал, - опять закрывая глаза, ответил гость, - что благодарит и не винит за то, что у него отняли жизнь.

- Кого? - глухо спросил Пилат.

- Этого он, игемон, не сказал. <...>

- <..> Единственное, что он сказал, это, что в числе человеческих пороков одним из самых главных он считает трусость.

- К чему это было сказано? - услышал гость внезапно треснувший голос.

- Этого нельзя было понять. Он вообще вел себя странно, как, впрочем, и всегда.

- В чем странность?

- Он все время пытался заглянуть в глаза то одному, то другому из окружающих и все время улыбался какой-то растерянной улыбкой [2, c. 296-297].

Иешуа отказывается от положенного по закону напитка, вежливо выражая признательность за предложение, и сообщает о том, что не обижа- 
ется на своих карателей, к тому же ведет себя странно - старается заглянуть в глаза всем, кто рядом, и растерянно улыбается. Иешуа не был распят на кресте, а повешен на столбе, к тому же, как известно из романа, умер не с именем Бога-Отца на губах, подобно Иисусу, а с именем Пилата. С тем, что такая аллюзия на Христа и на евангельский сюжет - кощунство, не будет никто спорить. Согласен с оценкой кощунственности и Андрей Кураев, однако он ставит вопрос: почему писатель именно так изобразил Иешуа и евангельскую историю и можно ли эту оценку перенести на весь роман?

Богослов последовательно доказывает, что писатель через «образ вроде-бы-Христа, образ, довольно заниженный и при этом не вызывающий симпатий у самого Булгакова» [7, с. ІІо], утрированно показывает совсем не свое антиевангельское видение фигуры Иисуса Христа: «Наиболее яркое (а на советском культурном пространстве и наиболее авторитетное) лицо, представлявшее эту версию, - это Лев Толстой. <...> Моралистика без мистики - вот “евангелие от Толстого”. Всепрощение, непротивление и никаких чудес и демонов» [7, c. III-II2]. Именно с таким взглядом на Христа, по мнению А. Кураева, полемизирует М. Булгаков через образ Иешуа Га-Ноцри.

Выбранный для анализа эпизод несет большую психологическую нагрузку через изображенную автором реакцию Понтия Пилата на полученную информацию о наказании Иешуа. Прокуратор мог помиловать его, но побоялся за свою судьбу в случае, если дело станет известно кесарю. Слова Га-Ноцри о том, что он никого не винит в своей смерти и о человеческой трусости Пилат справедливо воспринимает в свой адрес, поэтому его голос становится глухим и неожиданно «трескается». Этим психологическим рисунком подчеркивается странность поведения Иешуа, что способствует более глубокому пониманию эстетической концепции Михаила Булгакова, выступавшего против «евангелия от Толстого».

В романе «Мастер и Маргарита» игра на уровне референций, пародий, многозначности и метафоричности лексики, авторских проекций, текстологического параллелизма с религиозными и художественными произведениями других авторов является эстетическим приемом и коммуникативной стратегией текста, что обеспечивает высокую степень интертекстуальности произведения.

Как отметила исследователь творчества М. Булгакова Е. Иваньшина, «роман представлен читателю в осознании своей текстуальности (и интер- 
текстуальности), изображенная в нем реальность - в осознании ее вымышленности, а автор - в осознании своей таинственности» [3, с. г6]. В произведении сочетается несколько культурных и историко-религиозных традиций: античное язычество, иудаизм, раннее христианство, славянская мифология и западноевропейская средневековая демонология. Это, по утверждению другого исследователя литературного наследия М. Булгакова А. Леонтьева, «стало причиной чрезвычайно богатого интертекстуального состава романа и нашло свое отражение в сюжетной структуре, системе персонажей, их характеристиках, поэтике лексических средств, а также в цитации» $[8$, с. II].

Согласно утверждению Евы Леоновой, роман Владимира Короткевича «Христос приземлился в Городне» не претендует на изложение или толкование Библии, «не является он и художественной реконструкцией истории Христа <...>, а только развернутой аллюзией на нее» [9, с. г39], что с уверенностью можно сказать и о романе Михаила Булгакова «Мастер и Маргарита». Кроме того, эти произведения, имеющие антиатеистический характер, основаны на метаморфозах связей реального и ирреального миров, евангельская тематика в них подчинена освещению вопросов соотношения добра и зла, духовного и материального, истины и лжи, власти и справедливости. 


\section{Список литературы}

I Библия. Мн.: Беларусь, І990. I376 c.

2 Булгаков М.А. Мастер и Маргарита. Письма // Булгаков М.А. Собр. соч.: в 5 т. М.: Худож. лит., І990. Т. 5. 734 с.

3 Иваньшина Е.А. Автор - текст - читатель в творчестве Михаила Булгакова I930-х годов («Адам и Ева», «Мастер и Маргарита»): автореф. дис. ... канд. филол. наук. Воронеж, г998. 22 с.

4 Караткевіч У.С. Збор твораў у 8 тамах. Мн.: Мастацкая літаратура, г99о. Т. 6. Каментарый А.Л. Вераб’я. 492 с.

5 Караткевіч У. Хрыстос прызямліўся ў Гародні (Евангелле ад Іуды). Прадмова А. Вераб’я. Мн.: Беллітфонд, 2000. 496 с.

6 Короткевич В. Христос приземлился в Городне (Евангелие от Иуды) / пер. с белорусского и комментарий П. Жолнеровича. Мн.: Літаратура і Мастацтва, 201 I. $542 \mathrm{c}$.

7 Кураев А.В. «Мастер и Маргарита»: за Христа или против? М.: Проспект, 2016. I72 c.

8 Леонтьев А.А. Интертекст в романе М.А. Булгакова «Мастер и Маргарита»: автореф. дис. ... канд. филол. наук. М., 20ог. І7 с.

9 Лявонава Е.А. Алюзія на вобраз Хрыста ў рамане Уладзіміра Караткевіча «Хрыстос прызямліўся ў Гародні» і сусветная літаратурная традыцыя // Уладзімір Караткевіч і сучаснасць. Наваполацк: Пду, 20ог. С. І30-І42. Навойчык П.Іे. Антыклерыкальныя матывы ў творчасці У. Караткевіча // Русская и белорусская литературы на рубеже XX-XXI вв.: в 2 ч. Мн.: РИВШ, 2ого. Ч. І. C. 192-196. Нямиу А.Е., Лабай Е.В. Евангельский концепт в славянской литературе // Науковий вісник Чернівецького університету. 20II. Вип. 537. С. 68-72. 


\section{References}

I Bibliia [The Bible]. Minsk, Belarus' Publ., I990. I376 p. (In Russ.)

2 Bulgakov M.A. Master i Margarita. Pis'ma [The Master and Margarita. Letters]. Bulgakov M.A. Sobranie sochinenii: $v 5 t$. [Collected Works: in 5 vols.]. Moscow, Khudozhestvennaia literatura Publ., I990. Vol. 5. 734 p. (In Russ.)

3 Ivan'shina E.A. Avtor - tekst - chitatel'v tvorchestve Mikhaila Bulgakova I93o-kh godov ("Adam i Eva", "Master i Margarita"): avtoref. dis. ... kand. filol. nauk [The Author Text - Reader in the Work of Mikhail Bulgakov of the I930's (“Adam and Eve”, "Master and Margarita”): PhD thesis, summary]. Voronezh, I998. 22 p. (In Russ.)

4 Karatkevich U.S. Zbor tvoraw u 8 tamah [Collected Works: in 8 vols.]. Minsk, Mastackaia litaratura Publ., I990. Vol. 6, comm. by A.L. Verabei. 492 p. (In Beloruss.) $5 \quad$ Karatkevich U. Hrystos pryzjamliwsja w Garodni (Evangelle ad Iudy) [Christ landed in Gorodnya (Gospel of Judas)], introd. by A. Verabei. Minsk, Bellitfond Publ., 2000. 496 p. (In Beloruss.)

6 Korotkevich V. Khristos prizemlilsia v Gorodne (Evangelie ot Iudy) [Christ landed in Gorodnya (Gospel of Judas)], transl. from Belarusian and comm. by P. Zholnerovich. Minsk, Litaratura i Mastatstva Publ., 20II. 542 p. (In Russ.)

7 Kuraev A.V. "Master i Margarita”: za Khrista ili protiv? ["Master and Margarita”: for Christ or Against?]. Moscow, Prospekt Publ., 20I6. I72 p. (In Russ.)

8 Leont'ev A.A. Intertekst v romane M.A. Bulgakova "Master i Margarita": avtoref. dis. ... kand. filol. nauk [Intertext in M. Bulgakov's Novel "Master and Margarita”: PhD thesis, summary]. Moscow, 200I. I7 p. (In Russ.)

9 Ljavonava E.A. Aljuzija na vobraz Hrysta w ramane Uladzimira Karatkevicha "Hrystos pryzjamliwsja w Garodni” i susvetnaja litaraturnaja tradycyja [Allusion to the Image of Christ in the Novel of Vladimir Korotkevich "Christ landed in Gorodnya” and World Literary Tradition]. Uladzimir Karatkevich $i$ suchasnasc” [Vladimir Korotkevich and Modernity]. Navapolatsk, PDU Publ., 200I, pp. I30-I42. (In Beloruss.)

IO Navojchyk P.I. Antyklerykal”nyja matyvy w tvorchasci U. Karatkevicha [Anticlerical Motifs in the Work of V. Korotkevich]. Russkaia i belorusskaia literatury na rubezhe $X X-X X I v v .: v 2$ ch. [Russian and Belarusian Literature on the Frontier of the $2 \mathrm{O}^{\text {th }}-2 \mathrm{I}^{\text {st }}$ Centuries: in 2 parts]. Minsk, RIVSH Publ., 20I0, part I, pp. I92-I96. (In Beloruss.) Niamtsu A.E., Labai E.V. Evangel'skii kontsept v slavianskoi literature [The Concept of the Gospel in Slavic Literature]. Naukovii visnik Chernivets'kogo universitetu, 20II, issue 537, pp. 68-72. (In Russ.) 